\title{
An Analysis of the Relationship between Financial Development and Economic Growth: Evidence from the United Arab Emirates
}

Saima Shadab ${ }^{1 *}$

${ }^{1}$ Assistant Professor Aligarh Muslim University, Aligarh, U. P., India

DOI: $10.36348 /$ sjef.2021.v05i02.004 | | Received: 03.02.2021 | Accepted: 13.02.2021 | Published: 17.02 .2021

*Corresponding author: Saima Shadab

\section{Abstract}

This study examines the relationship between the financial sector and economic growth for the United Arab Emirates, which is presently the most successfully diversified economy among the six Gulf Cooperation Council Countries (commonly referred as the GCC). The time period covered for this purpose is from 1975 to 2016. Since the present study deals with time series analysis, various time series techniques were employed to examine the relationship between financial sector and economic growth. The Augmented Dickey Fuller (ADF) unit root test was employed to check the variables stationarity, followed by lag length criteria test to define optimal lag length and proceed with the cointegration test. Finally, Vector Error Correction Model test (VECM) and Granger Causality test were employed to determine the relationship by using domestic credit to private sector, broad money (M2) and FDI as proxy variables to measure financial development, and GDP per capita (constant 2010 US\$) as proxy variable for measuring economic growth. The results obtained from the analysis revealed that broad money and private sector credit play a crucial role in the development of the financial sector in the UAE.

Keywords: Economic Growth, Financial Development, Domestic Credit, Broad Money, FDI.

Copyright (C) 2021 The Author(s): This is an open-access article distributed under the terms of the Creative Commons Attribution 4.0 International License (CC BY-NC 4.0) which permits unrestricted use, distribution, and reproduction in any medium for non-commercial use provided the original author and source are credited.

\section{INTRODUCTION}

The importance of the development of a sound financial sector and its role in increasing and stabilizing the economic growth in a country was first and foremost emphasized by Schumpeter, J. A. [1]. The development and expansion of the financial sector of a country is imperative as it plays the role of increasing economic growth by boosting economic activities through the creation of productive real investments, savings, and expansion of private sector by providing credit to private firms/companies, the contributions through market capitalization, and also through innovations and increase in the role of entrepreneurs in the economy. There is an enormous amount of research conducted to test whether or not any significant relationship between financial development and economic growth is prevalent. However, in their study, Zarrouk, H., El Ghak, T., \& Abu Al Haija, E. rightly asserted that a well-developed financial sector generates financial resources that are utilized in productive investments that in turn boost the economic growth. The development of the financial sector is, therefore, paramount to achieve stable and sustainable economic growth in a country [2].

Despite its significant role and contribution, research studies are relatively limited on the financial sector, its development and contribution to economic growth for the UAE. Also, a vast amount of available literature yields contradictory results, more specifically due to the recent financial crisis that has put the role of financial sector in promoting economic growth as a matter of debate [3].

Therefore, the aim of the study is to investigate this complex relationship between financial development and economic growth specifically for the UAE. The financial sector of the UAE plays a pertinent role in the economy's development and expansion of its non-oil sector. The Dubai International Financial Corporation (DIFC) is one of the most eminent contributions towards the development of the UAE's financial sector as it is the greatest attraction to invite foreign banks to the UAE economy by providing them an unrestricted and free financial market [4]. 
In this study, financial development has been measured by domestic credit to private sector as a percentage of GDP and broad money as a percentage of GDP (i.e., M2). Such proxy variables for financial development have been employed in similar studies conducted by [5- 8] and Durham [9]. Figure 1 graphically sums up the performance of some of the selected major financial development indicators. As evident from Figure 1, the development of financial sector in the UAE economy has increased and improved greatly over the period 2001-2016. All the three ratios; domestic credit to private sector as a percentage of GDP, financial system deposits as a percentage of GDP and Broad Money Supply as a percentage of GDP witnessed an increasing trend, despite the severe financial crisis that happened in 2008. In other words, for the UAE economy, the financial sector witnessed an overall improvement during the period of 2001-2016. In his study, Muyambiri, B., \& Odhiambo, N. M. asserts that an increase in monetary aggregates such as M1, M2 or M3 to the GDP implies an increase in the financial assets [10]. Therefore, keeping this in view, in this paper, the ratio M2/GDP has been taken in consideration which is a crucial indicator of the size and depth of a country's finance sector. It can be observed from Figure 1, that the ratio has substantially increased from $40 \%$ in 2001 to around $90 \%$ in 2016. The domestic credit to private sector ratio is another important proxy measure of analysing the financial sector's depth and development of a country [10]. It may also be observed from the figure that the domestic credit to private sector and financial systems deposit ratio also increased significantly from around 34 per cent levels in 2001 to 83 and 90 per cent levels in 2016, respectively. However, a closer analysis from the data reveals that over the period 2011-2014, both the financial development ratios had declined steeply from 74 per cent in 2010 to around 60 per cent levels in the period 2011-2014. One major reason that has to be attributed behind this downtrend is the oil price downturn which led to huge increase in government debt, cut of many investment projects and overall economic instability in the GCC region. However, both the indicators show recovery and increase thereafter. In short, it is clear from the figure that in terms of development of the financial sector, the UAE has successfully attained appreciable improvement over the years.

This study is a contribution to the existing literature because a longer time period of study i.e., 1975-2016 has been taken into account and the econometric model includes the role of FDI in financial development the UAE economy. There is a vast amount of literature that consists of empirical studies conducted to investigate the relationship between finance sector and economic growth, out of which, many support the view that there is a positive relationship between economic growth and the development of financial sector. Shahbaz, M., Rehman, I. U., \& Muzaffar, A. T. rightly asserted in their study on financial development in Bangladesh that financial development is the channelling of savings into productive investments through the help of various financial institutions [3]. Empirical studies that investigated the relationship between financial development and growth in the United Arab Emirates are limited in number and scope as they mainly focus on financial sector's development by highlighting the contribution of Islamic Finance Development in economic growth. For instance, Zarrouk, H., El Ghak, T., \& Abu Al Haija, E. examined the directional relation between the financial sector and economic growth in the UAE economy for the period 1990-2012 [2]. The main focus of their study was to examine the impact of Islamic finance on economic growth and also to study the impact of financial development on economic growth in the UAE. Findings of their study revealed that a unidirectional causality running from GDP to Islamic finance exists for the UAE.

Another important study related to the contribution to economic growth through the development of the finance sector was investigated by Al-Malkawi, H. A. N., Marashdeh, H. A., \& Abdullah, $\mathrm{N}$. in which they examined the causal relationship between GDP (economic growth) and financial development over the period 1974 to 2008 using two different variables ; 1 . Size of the financial sector measured via proxy variable "M2/GDP" and 2. Percentage contribution of private credit by banks to GDP [11]. The final results of this study revealed a twoway causal relationship between economic growth and the monetization ratio $\mathrm{M} 2$ in the UAE economy. However, no relationship between domestic credit and economic growth was found.

Tabash, M. I., \& Dhankar, R. S. analysed the impact of Islamic finance on economic growth using FDI, Gross Fixed Capital Formation and Real GDP as proxy variables to measure economic growth over the period 1990-2010 [12]. Findings from their study revealed a one directional causal relationship from Islamic Finance to Economic Growth. Similarly, a oneway causal relationship from Islamic finance to investment was found while a bidirectional causal relationship was found between FDI and Islamic finance. Therefore, the study proves that Islamic finance plays a pivotal role in the development of the financial sector and economic growth in the UAE economy.

In a study conducted by Mosesov, A., \& Sahawneh, N. M. F. examined the size and impact of financial sector in the UAE and found that the financial sector of the UAE has no significant impact on its economic growth [13]. Similarly, Okafor, I. G., Ezeaku, H. C., \& Ugwuegbe, U. S. examined the same relationship in Nigeria from 1981 to 2014 [14]. They examined financial development through 1. Broad 
Money (M2) and 2. Credit to private sector and found that there is no causal relationship between financial development and economic growth. Further, there is a one-way causal relationship from M2 to Private Sector Credit.

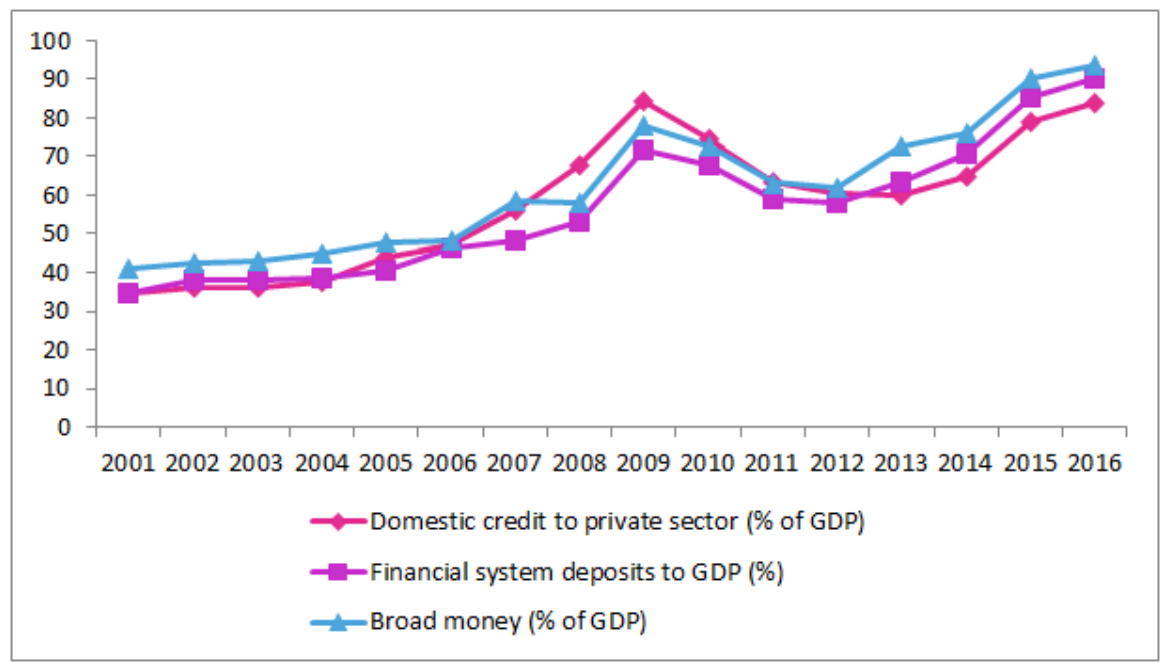

Fig-1: UAE's FINANCIAL SECTOR'S PERFORMANCE FROM 2001-2016

Source: Author's own figure. Data is obtained from World Development Indicators

In this section, a brief background of this study had been discussed. The rest of this research paper has been organized as follows: section two consists of methodology and econometric model used in this study. Section three deals with results and analysis obtained from econometric tests conducted. The last section of this paper comprises of final conclusion.

\section{Methodology, Study Period, Specification of the Variables and Econometric Model}

This study examines the relationship between financial development and its impact on the economic growth of the UAE. The following variables were incorporated in the study:

1. Domestic credit to private sector as a percentage of GDP (referred as DC in short in this paper) as a proxy variable to measure the extent and impact of financial development across UAE.

2. Per Capita Gross Domestic Product in Constant 2010 US \$ (Abbreviated as GDP in this paper) as a proxy variable to measure economic growth in the UAE economy

3. Foreign Direct Investment, Net Inflows as a percentage of GDP (represented by FDI in this paper) is again a measure of economic growth as FDI has technology spill over effects and also brings about increase in employment opportunities and skilled human resources.

4. Broad Money as a percentage of GDP (BM) to reflect the size/depth of finance sector in the UAE.

Data for all the variables has been compiled from the database of World Development Indicators (WDI). The time period taken in consideration of the variables GDP, DC, FDI AND BM is 1975-2016 (41 years) respectively.

Therefore, the following model has been tested empirically to investigate the development of financial sector in the UAE and its relation with economic growth:

$\mathrm{Y}=\mathrm{f}(\mathrm{DC}, \mathrm{FDI}, \mathrm{BM}) \ldots \ldots .$. Equation no. 1$\}$

Where Y depicts Per capita GDP, DC is Domestic Credit to private sector as a percentage of GDP, FDI relates to Foreign Direct Investment Inflows (as a percentage of GDP) and BM is Broad Money (also commonly known as M2 money supply function).

The analysis has been conducted as follows: Firstly, in order to empirically examine the development of finance sector and its relation with economic growth in the economy of UAE, the study conducts stationarity test using the ADF unit root test on all the four variables for which the results have been shown in Table 1. In the next step, the study employ's lag selection test and from the results obtained, AIC has been undertaken to identify the number of lags that have to be taken for further analysis. To proceed further, the study employed the Johansen co integration test to check whether any of the variables are found to be co integrated in the long-run. Since the results depict the presence of cointegration, the study incorporates Vector Error Correction test to examine the long-run relationship. Lastly, VEC Granger Causality Test was employed on the variables to check for causal relationship between financial development and economic growth in the UAE.

\section{RESULTS AND DISCUSSION}




\section{Results from Unit Root Test}

The results (as shown in table 1) from the test revealed that the data for each variable was not found stationary at level. However, the variables were found stationary at first difference at $1 \%, 5 \%$ and $10 \%$ significance levels.

Table-1: Unit Root Test (ADF)

\begin{tabular}{|c|c|c|c|}
\hline Variables & P value at Level* & P value at First Difference** & Final Outcome (at 1\%, 5\% and 10\% level) \\
\hline GDP & 0.6456 & 0.0004 & Stationary at First Difference \\
\hline DC & 0.8102 & 0.0002 & Stationary at First Difference \\
\hline FDI & 0.2638 & 0.0000 & Stationary at First Difference \\
\hline BM & 0.9840 & 0.0000 & Stationary at First Difference \\
\hline
\end{tabular}

*And ** indicates "intercept" was included in test equation while testing for unit root. Source: Author's own.

\section{Results from VAR Lag Selection Criteria Test}

Before performing cointegration test, the study determines the optimal lag length as depicted in table 2 . As depicted in the table, the optimal lag length is three in accordance with the LR test statistic (LR), Final prediction error (FPE), and Akaike Information Criterion (AIC). However, following the Schwarz information and Hannan-Quinn information criterion, the optimal lag determined is one. Therefore, this study follows Akaike Information criterion (AIC), and therefore the lag length three has been used for testing cointegration and granger causality among the variables. This choice is relevant as firstly, for annual data, the number of lags is usually small and ranges between 1-2. Secondly, too many lags lead to loss of degrees of freedom. Thirdly, AIC is the most widely preferred criterion to select optimal lag length for time series analysis.

Table-2: Var lag selection

\begin{tabular}{|c|c|c|c|c|c|c|}
\hline LAG & LogL & LR & FPE & AIC & SC & HQ \\
\hline 0 & -310.272 & NA & 117.3377 & 16.11652 & 16.28714 & 16.17774 \\
\hline 1 & -183.984 & 220.1941 & 0.412674 & 10.46074 & $11.31384 *$ & $10.76682 *$ \\
\hline 2 & -168.174 & 24.32354 & 0.42862 & 10.47046 & 12.00606 & 11.02142 \\
\hline 3 & -1464494 & $28.96619^{*}$ & $0.343457 *$ & $10.17689 *$ & 12.39497 & 1097272 \\
\hline
\end{tabular}

*Lag order selected according to the criterion

LR: Sequential modified LR test statistic (each test a

$5 \%$ level)

FPE: Final Prediction Error

AIC: Akaike Information Criterion

SC: Schwarz Information Criterion

HQ: Hannan-Quinn Information Criterion

\section{Johansen Cointegration Test Results}

The result obtained from the Johansen Cointegration test has been displayed in Table 3. The presence of cointegration and therefore, a long-run relationship exists when the trace statistic and maximum eigen values exceed the critical values. As evident from the table, trace statistics and maximum eigen values are more than the critical values for more two hypotheses at five percent critical value, respectively. This implies that there is a long term relationship among variables due to the existence of at least two cointegrating relationship.

Table-3: Johansen Cointegration Test (Trace Statistic)

\begin{tabular}{|l|l|l|l|}
\hline $\begin{array}{l}\text { HYPOTHESES OF } \\
\text { CE }\end{array}$ & $\begin{array}{l}\text { TRACE } \\
\text { STATISTIC }\end{array}$ & $\begin{array}{l}\text { CRITICAL VALUE AT 5 PER CENT } \\
\text { LEVEL }\end{array}$ & $\begin{array}{l}\text { P } \\
\text { VALUE** }\end{array}$ \\
\hline NONE* & 100.8157 & 47.85613 & 0.0000 \\
\hline AT MOST 1 & 36.92015 & 29.79707 & 0.0064 \\
\hline AT MOST 2 & 7.743717 & 15.49471 & 0.4932 \\
\hline AT MOST 3 & 1.034126 & 3.841466 & 0.3092 \\
\hline \multicolumn{4}{|l}{} \\
*implies the rejection of null hypothesis at 5 percent \\
** denotes McKinnon-Haug-Michelis(1999) p-values
\end{tabular}

Table-3: Johansen Cointegration Test (Maximum Eigenvalue)

\begin{tabular}{|l|l|l|l|}
\hline $\begin{array}{l}\text { HYPOTHESES OF } \\
\text { CE }\end{array}$ & $\begin{array}{l}\text { MAXIMUM EIGEN } \\
\text { STATISTIC }\end{array}$ & $\begin{array}{l}\text { CRITICAL VALUE AT 5 PER } \\
\text { CENT LEVEL }\end{array}$ & $\begin{array}{l}\text { P } \\
\text { VALUE** }\end{array}$ \\
\hline NONE* & 63.89553 & 27.58434 & 0.0000 \\
\hline AT MOST 1 & 29.17643 & 21.13162 & 0.0030 \\
\hline AT MOST 2 & 6.709591 & 14.26460 & 0.5240 \\
\hline At MOST 3 & 1.034126 & 3.841466 & 0.3092 \\
\hline
\end{tabular}


Vector Error Correction Model (VECM) Test Results

VEC results

Sample: 1978-2016

Standard Errors are displayed in ( ) and t-values in [ ]

Table-4: Long run relationship

\begin{tabular}{|l|l|}
\hline Cointegrating Equations: & CointEq1 \\
\hline GDP & 1.000000 \\
\hline FDI & -42949.53 \\
& $(8374.93)$ \\
& {$[-5.12835]$} \\
\hline Broad Money & 132.8831 \\
& $(2420.21)$ \\
& {$[0.05491]$} \\
\hline Domestic Credit & 4154.373 \\
& $(2480.41)$ \\
& {$[1.67487]$} \\
\hline C & -172175.2 \\
\hline
\end{tabular}

As evident from the long run relationship that has been displayed in Table 4, there exists no significant relationship between Economic Growth (GDP) and any of the financial development variables M2, FDI and Domestic Credit because t values are less than 1.96 per cent. A positive sign of coefficient indicates a negative relationship and a coefficient with negative sign implies a positive relationship between the dependent and independent variables. However, analysis of coefficients reveals that there is positive association between FDI and GDP and negative relationship between GDP, BM and DC in the long run. The result of negative relation between BM and GDP is also consistent with Al-Malkawi, H. A. N., Marashdeh, H. A., \& Abdullah, N. study on UAE's financial development [11]. The reason attributed to this negative relationship in their study is that the UAE is still in its structural transformation phase and prone to a weak economic and financial environment due to dependency upon the oil sector to a certain extent. This explanation is acceptable because the UAE is still lagging behind in attaining complete self-sufficiency from oil dependency, oil price fluctuations and its impact, and is still in the process of diversifying. Complete success of diversification in the UAE can be only known in the long run, maybe, after the completion of the VISION plan in 2021 [15].

\section{Results from the Granger Causality Test}

Results from the Granger Causality test have been summarized in table 5 .

Table-5: Results from vector error correction granger causality/block exogeneity wald test.

\begin{tabular}{|l|c|c|c|c|}
\hline DEPENDENT VARIABLES & \multicolumn{4}{l|}{ INDEPENDENT VARIABLES } \\
\hline \multirow{3}{*}{ BM } & $B M$ & DC & FDI & GDP \\
\cline { 2 - 5 } DC & --- & $0.0001 * * *$ & 0.2041 & 0.9224 \\
\hline FDI & $0.0000^{* * *}$ & --- & $0.0002 * * *$ & $0.0506 * *$ \\
\hline GDP & 0.5083 & 0.3885 & --- & 0.8295 \\
\hline \multicolumn{6}{|l}{ ***, and ** denotes level of significance at 1 percent and 10 percent. } \\
\hline
\end{tabular}

It can be inferred from the results that there runs a significant and unidirectional relationship from Domestic Credit to Private Sector (\% of GDP) to FDI. Similarly, a one-way causal effect exists from Domestic Credit to GDP in the UAE. A short-run significant bidirectional causal relationship between DC to BM at one percent level of significance. This shows that the size of financial sector, as represented by the variable Broad Money or BM is significant and contributory to the development of credit to private sector. Also, the extent of domestic credit to private sector is quite important and impactful towards for the development of the financial sector. The relationship between broad money and private sector credit has been examined in many studies such as [7] and [8]. For instance, in Okafor, I. G., Ezeaku, H. C., \& Ugwuegbe, U. S.'s study a unidirectional relationship between broad money and domestic credit to private sector was observed and there was no directional relationship between GDP and BM or DC and GDP in their study [14].

The results also reveal a unidirectional causal relation exists from GDP to BM. This signifies that economic growth leads to the development of the financial sector in the UAE in the short-run. Similarly, a one-way relation also exists from DC to GDP which indicates the important role of credit to the private sector in boosting economic growth of the UAE.

One of the most important results to be noted from the present study is that of the overall impact of financial development on economic growth of the UAE economy. Financial Development in this study is reflected through the variable Domestic Credit to Private Sector. This implies that the UAE government needs to take more appropriate efforts and initiatives for the development of a sound financial sector that could contribute significantly to the economic growth and stability of the UAE economy.

\section{CONCLUSION}

The main objective of this research paper is to examine the relationship between financial sector and economic growth in the UAE economy. This was done 
by conducting Granger Causality (Block Exogeneity Wald Test) test on four important variables which are of financial nature, namely, Domestic Credit to Private Sector, Broad Money (M2), Foreign Direct Investment Inflows or FDI inflows (as a percentage of GDP) and lastly, GDP. The time period taken in consideration for this research study was from 1975 to 2016 . The findings from tests revealed that in the UAE economy, financial development and economic growth do not share any significant relationship in the long run i.e. financial sector fails to impact UAE's economic growth and vice versa. However, one noteworthy finding is the existence of a (short run) bi-directional causal relationship between Broad Money (M2) and Domestic Credit to Private Sector in the UAE, which depicts the importance of private sector credit in the financial sector. The results also reveal a unidirectional causal relation exists from GDP to BM. This signifies that economic growth leads to the development of the financial sector in the UAE in the short-run. Similarly, a one-way relation also exists from DC to GDP which indicates the important role of credit to the private sector in boosting economic growth of the UAE in the short-run.

Comparing our results with previous studies in which time period usually was from 1975-2008 we can state that the UAE's financial development has improved since then. However, the government has to take active intervention through appropriate policies and initiatives for making the finance sector in UAE contributory to the economy's growth and stability.

A limitation of this study is that the impact of Islamic financial development on economic growth has been completely ignored. This is because research studies on UAE's financial development have already been discussed and have empirically tested the relationship between Islamic finance and economic growth in the UAE. However, very few research studies have been conducted that simply test the relationship between financial sector (as a whole) and economic growth in the UAE. Therefore, the scope of this study is not limited to solely Islamic finance.

\section{REFERENCES}

1. Schumpeter, J. A. (1912). The Theory of Economic Development Harvard Economic Studies. Cam'bridge.

2. Zarrouk, H., El Ghak, T., \& Abu Al Haija, E. (2017). Financial development, Islamic finance and economic growth: evidence of the UAE. Journal of Islamic Accounting and Business Research, 8(1), 222.
3. Shahbaz, M., Rehman, I. U., \& Muzaffar, A. T. (2015). Re- Visiting Financial Development and Economic Growth Nexus: The Role of Capitalization in B angladesh. South African Journal of Economics, 83(3), 452-471.

4. Hashmi, M. A. (2007). An analysis of the United Arab Emirates banking sector. International Business and Economics Research Journal,6(1), 77.

5. Alfaro, L., Chanda, A., Kalemli-Ozcan, S., \& Sayek, S. (2004). FDI and economic growth: the role of local financial markets. Journal of international economics, 64(1), 89-112.

6. Azman-Saini, W. N. W., Law, S. H., \& Ahmad, A. H. (2010). FDI and economic growth: New evidence on the role of financial markets. Economics letters, 107(2), 211-213.

7. Sbia, R., \& Al Rousan, S. (2015). Does Financial Development Induce Economic Growth in UAE? The Role of Foreign Direct Investment and Capitalization.

8. Shahbaz, M., Leitão, N. C., \& Malik, S. (2011). Foreign direct investment-economic growth nexus: the role of domestic financial development in Portugal. Economics Bulletin, 2824-2838.

9. Durham, J. B. (2004). Absorptive capacity and the effects of foreign direct investment and equity foreign portfolio investment on economic growth. European economic review, 48(2), 285 306.

10. Muyambiri, B., \& Odhiambo, N. M. (2014). A chronological analysis of monetary policy and the financial system in South Africa. Public and Municipal Finance, 3(2), 19-29.

11. Al-Malkawi, H. A. N., Marashdeh, H. A., \& Abdullah, N. (2012). Financial development and economic growth in the UAE: Empirical assessment using ARDL approach to cointegration. International Journal of Economics and Finance, 4(5), 105-115.

12. Tabash, M. I., \& Dhankar, R. S. (2014). Islamic finance and economic growth: empirical evidence from United Arab Emirates (UAE). Journal of Emerging Issues in Economics, Finance and Banking, 3(2), 1069-1085.

13. Mosesov, A., \& Sahawneh, N. M. F. (2005). UAE: Financial development and economic growth. Skyline Business Journal, 1, 1-11.

14. Okafor, I. G., Ezeaku, H. C., \& Ugwuegbe, U. S. (2015). Relationship between deposit money bank credit and economic growth in Nigeria under a VAR G-causality environment. Iosr Journal of Economics and Finance, 7(2), 41-46.

15. Vision, U. A. E. (2021). (nd). UAE vision 2021brochure-English-pdf. 